\title{
Documenting Religion Worldwide: Decreasing the Data Deficit
}

\begin{abstract}
Religion's prominence in national and international affairs makes the availability of empirical measures on religion a pressing concern for researchers, policy makers, and data archivists. Unfortunately, good international religious data are scarce. This paper describes the expanded mission of the Association of Religion Data Archives (www.TheARDA.com) to archive and develop data on religion worldwide. The ARDA archives data on 238 different countries and territories including ARDA-coded measures for 195 countries from the US State Department's annual International Religious Freedom Reports. This paper highlights three important indexes developed by the ARDA that contribute to a better understanding of religion and religious tensions around the globe. These data are freely accessible online and available for download

Despite the increasingly obvious role of religion in national development and global relations, international data on religion are few, scattered, and often difficult to access. A recent review concludes that the study of world politics runs the "risk of stagnation" unless data are updated (Bremer, Regan, \& Clark, 2003). Data sets which are available, such as the Minorities at Risk [coding] Project, have limited measures that are specifically focused on religion as a category distinct from ethnicity. Other crossnational studies, such as the World Values Study (WVS) and the International Social Survey Programme (ISSP) with multiple measures on religion, have few data that specifically relate to such important topics as religion and conflict. Such a topic is not of trivial interest. A recent Pew Research Center poll of the U.S. public (2005) found that three-quarters of the public consider that religion either has a great deal (40 percent) or a fair amount ( 35 percent) to do with most wars and conflicts in the world today.
\end{abstract}

To address the data deficiency on worldwide religion, the Association of Religion Data Archives (www.TheARDA. com) is pursing an international religion data initiative to archive key religion indicators for 238 different countries and territories. The ARDA, housed at the Pennsylvania State University, is unique among the major academic data archives in that it focuses on the specific topic of religion. This offers several advantages. First, it archives data collections that might be excluded from more general or regional archives. Second, it assists users in finding quality data that are embedded in larger social scientific studies, such as the ISSP, the WVS, and the General Social Survey (GSS). Third, it provides more support information and metadata that are customized for users interested in the topic of religion. And, fourth, online software and web features are customized for the topic at hand.

Currently, the ARDA's international online collection includes several different types of data on religion including the World Christian Encyclopedia's data on adherents of major religious traditions (Barrett, Kurian, \& Johnson, 2001). Religion variables from the ISSP survey and four waves of the World Values Survey will soon be highlighted and available for online analysis at The ARDA. The collection also has other important international measures, including: Freedom House's indexes on political rights, civil liberties, religious freedom, and freedom of the press; basic economic measures such as purchasing power parity (PPP), income inequality (GINI index), and the Heritage Foundation's index of economic freedom; and key United Nations indexes such as the human development index (HDI) and the gender-related development index (GDI). Providing these measures in one site and in one downloadable data set improves access to such data, increases the use of the data, and allows comparisons between countries and regions of the world.

Unique to the ARDA collection are coded measures on the religious situation in 195 different countries based on the U.S. State Department's International Religious Freedom Reports (2003). (For details on the coding and inter-rater reliability statistics see Grim \& Finke, 2006; also see Grim, Finke, Harris, Meyers, \& Van Eerden, 2006.) These annual reports to Congress were mandated by the 1998 International Religious Freedom Act and are one of the most comprehensive global treatments of social and political factors related to religion. Though the Report's title rightly indicates a focus on religious freedom, the Reports detail many issues related to religion including situations where religious actors are either perpetrators or victims of conflict and/or violence. Each U.S. Embassy 
follows a common set of guidelines and training is given to Embassy and State Department personnel who investigate the situation and prepare the Reports (see U.S. State Department 2001-2005).

The reports cover the following standard reporting fields for each country: religious demography, legal/policy issues, restrictions of religious freedom, abuses of religious freedom, persecution by terrorist organizations, forced conversions, improvements in respect for religious freedom, and the US Government's actions. The U.S. State Department has been compiling such annual Reports since 1997. In 2001, they took on the reporting format shown in Figure 1. to religion. It is sobering to see that, in countries with populations of at least two million, the presence of religious tension is the norm ( 84 percent). For those in the West, these religious tensions may be less present, given that tensions based on religion are reported in only 64 percent of the countries, much below the world norm. But, as the Pew poll cited above reveals, these tensions are nonetheless felt.

Knowing that tensions are present is useful information, but it is even more useful to have measures that can help understand the government and social factors related to these tensions. The ARDA provides indexes for three important dimensions of religion in society that are related to these tensions: government regulation of religion index (GRI), government favoritism of religion index (GFI), and social regulation of religion index (SRI). Each of these measures is significantly correlated with the presence of religious tensions. 4

The first index (GRI) is based on a set of questions related to the government regulation of religion. This is the most visible form of regulation for outsiders and the one

One of the measures coded by Grim and Finke (2006) was whether tensions related to religion are present in the country (see Table 1). It may come as no surprise that every country in South Asia3 has tensions related that receives the most attention from theory and research. Grim \& Finke (2006, p. 7) define government regulation as the restrictions placed on the practice, profession, or selection of religion by the official laws, policies, or administrative actions of the
Table 1: Tensions related to religion

\begin{tabular}{|c|c|c|}
\hline & $\begin{array}{l}\text { Tensions } \\
\text { related to } \\
\text { religion }\end{array}$ & $\begin{array}{l}\text { Countries with } \\
\text { populations } \\
\text { greater than } \\
\text { million; } \mathrm{N}=\end{array}$ \\
\hline Africa & $83 \%$ & 35 \\
\hline East Asia \& Pacific & $80 \%$ & 20 \\
\hline Europe \& Eurasia & $88 \%$ & 42 \\
\hline Near East \& North Africa & $94 \%$ & 17 \\
\hline South Asia & $100 \%$ & 7 \\
\hline Western Hemisphere & $68 \%$ & 22 \\
\hline All countries $>2$ million pop. & $84 \%$ & 143 \\
\hline
\end{tabular}
state. The index is built upon measures that are not just limited to the formal laws of the state. Although the vast majority of countries promise religious freedom in their constitution, they often support administrative sanctions or open hostilities toward specific groups. Moreover, minority groups can face battles for zoning approvals, tax-exemption status, and public corporation status. Thus, restrictions against religions can come in the form of blatant laws against their existence or more subtle policy restrictions that limit their operations.

Actions of the state, however, are also supportive of religion. Indeed, many countries openly favor select religions. Grim \& Finke's 
second index (GFI) is a measure of government favoritism of religion, which they define as subsidies, privileges, support, or favorable sanctions provided by the state to a select religion or a small group of religions (2006, p. 8). This favoritism can come in many forms. Like government regulation, subsidies can be constitutional guarantees or they can result from the more capricious actions of administrative offices. The most obvious are specific regulation of religion, 89 percent have some sort of government favoritism of religion, and 83 percent have some level of social regulation of religion. Interestingly, the countries of the Western Hemisphere are more similar to the mean of all other countries with populations of two million or more in terms of government favoritism (4.7 compared to 4.8), but less similar when considering government regulation (1.4 versus 3.5) (see Table 2). It is

Table 2: Government regulation and favoritism, and social regulation of religion

\begin{tabular}{|l|c|c|c|c|}
\hline \multirow{2}{*}{$\begin{array}{l}\text { Extent to which countries } \\
\text { regulate and/or favor certain } \\
\text { religions }\end{array}$} & $\begin{array}{c}\text { Mean level* of: } \\
\text { Regulation of } \\
\text { Religion (GRI) }\end{array}$ & $\begin{array}{c}\text { Government } \\
\text { Favoritism of } \\
\text { Religion (GFI) }\end{array}$ & $\begin{array}{c}\text { Social Regu- } \\
\text { lation of Reli- } \\
\text { gion (SRI) }\end{array}$ & $\begin{array}{c}\text { Countries } \\
\text { with popula- } \\
\text { tions greater } \\
\text { than } \\
\text { million; N }\end{array}$ \\
\hline Africa & 3.0 & 3.2 & 3.4 & 35 \\
\hline East Asia \& Pacific & 4.4 & 3.9 & 3.4 & 20 \\
\hline Europe \& Eurasia & 3.1 & 5.3 & 3.7 & 42 \\
\hline Near East \& North Africa & 6.2 & 7.5 & 8.3 & 17 \\
\hline South Asia & 6.3 & 6.4 & 8.4 & 7 \\
\hline Western Hemisphere & 1.4 & 4.7 & 2.0 & 22 \\
\hline All countries > 2 million pop. & 3.5 & 4.8 & 4.1 & 143 \\
\hline \multicolumn{2}{|c|}{ * Range 0-10, with 10 being the highest level of regulation or favoritism }
\end{tabular}

constitutional privileges and the financial subsidies directly supporting religious institutions. Less obvious are the supports of state institutions and administrations for such things as the teaching of religion in state supported schools and subsidy of service institutions run by religious groups.

Religious regulation is more than just the laws, policies, and administrative actions of a government. The third index (SRI) provides a measure of the social regulation of religion that moves beyond the realm of the state. Grim \& Finke (2006, p. 8) define social regulation as the restrictions placed on the practice, profession, or selection of religion by other religious groups, associations, or the culture at large. This form of regulation might be tolerated or even encouraged by the state, but is not formally sanctioned or implemented by government action. Social regulation can be extremely subtle, arising through the pervasive norms and culture of the larger society, or it can include blatant acts of persecution by militia groups. Often, though not always, this form of regulation is a product of religion. Religion itself can regulate other religions. Like other groups, religions seek to gain advantage by forming cartels and alliances that can regulate the culture and give the group a competitive advantage.

Regulation and favoritism of religion within countries is widespread. Of the 143 countries with populations of two million or more, 76 percent have some form of government also interesting to note that the mean for social regulation of religion is highest in South Asia (8.4) and the Near East and North Africa (8.3), both regions of the world experiencing high levels of conflict today.

Our intent here is not to provide an explanatory model of religion and conflict; rather, we have briefly highlighted examples of the types of data currently available at the ARDA on worldwide religious tensions, government regulation of religion, government funding of religion, and social regulation of religion. These are data researchers can use to better study religious tension and conflict in the world.

These new measures are just one part of the ARDA's new initiative to generate, assemble, and disseminate international data on religion. One of the chief aims is to make such data available in ways that reach multiple audiences. A user-friendly website for each country helps to accomplish this aim (see Figure 2).

The religious regulation and favoritism measures, in addition to other information, are clearly visible on the country Summary page. Intriguing statistics are also found, such data showing that Saudi Arabia is only estimated to be 92.7 percent Muslim, due to the large number of foreign workers resident in the country who come from many different faiths, including at one time, the lead author of 
Figure 2: Web shot of a country page

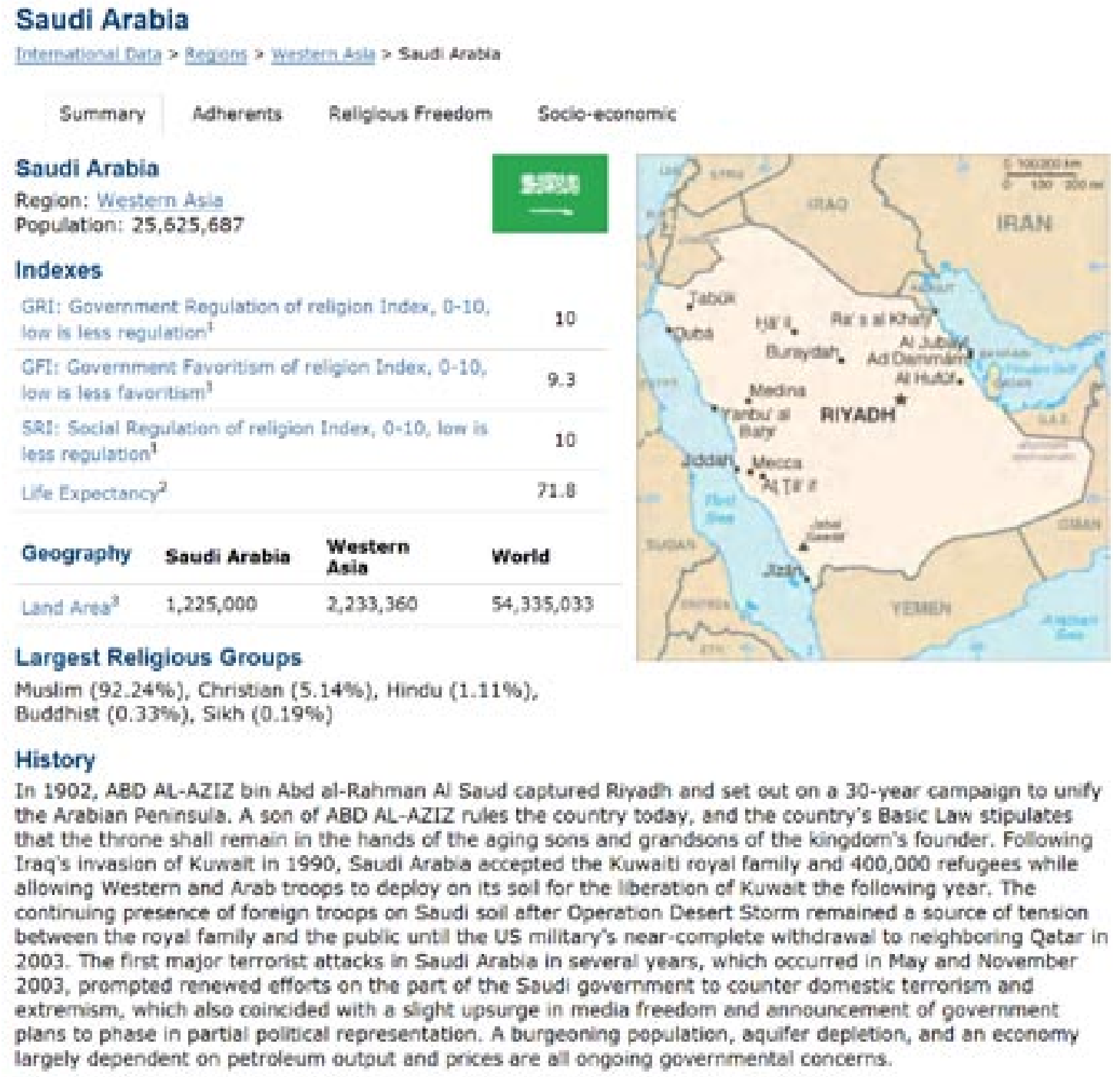

Sources

this paper. Tabbed pages for each country take the visitor to additional information on Adherents, Religious Freedom, and Socio-economic conditions in each country. Additional Tabs will be added, including one planned for public opinion surveys related to religion done in the country, e.g., highlighting key variables from the World Values Survey and the International Social Survey Programme (ISSP). The web site also provides easy links to many downloadable data sets and their sources.

In the years ahead, the ARDA will continue to expand its collection of data specifically related to religion around the world and make these data freely available to the general public. Additional online software tools for creating reports, graphs, and maps will also be developed as well as other online resources including press releases, summary reports, tutorials, information software tools, and user support. Finally, the ARDA is producing a series of publications addressing the technical issues of creating indexes from the data (e.g., Grim \& Finke, 2006) and initiating debate on the key substantive issues (e.g., religion's relationship to peace, war, health, and democracy). International and interdisciplinary in scope, the International Initiative's new data, press releases, online resources, and publications also aim to contribute to the agenda for future research and provide solid resources for informed public discourse on international religion.

\section{Refrences}

Barrett, D.B. Kurian, G.T., \& Johnson, T.M. (2001). World Christian Encyclopedia: A Comparative Survey of Churches and Religions in the Modern World, 2nd Ed. 
New York: Oxford University Press.

Bremer, S., Regan, P.M., \& Clark, D.H. (2003). Building a Science of World Politics: Emerging Methodologies and the Study of Conflict. The Journal of Conflict Resolution 47: 3-12.

Grim, B.J., \& Finke, R.. (2006). International Religion Indexes: Government Regulation, Government Favoritism, and Social Regulation of Religion. Interdisciplinary Journal of Research on Religion 2, Article 1. Internet www. religjournal.com.

Grim, B.J., Finke, R., Harris, J., Van Eerden, J., \& Meyers, C. (2006). Measuring International Socio-Religious Values and Conflict by Coding U.S. State Department Reports. Paper presented at the American Association of Public Opinion Researchers (AAPOR) annual conference, Montreal, May 18-21, 2006.

Pew Research Center. (2005). Views of Muslim-Americans Hold Steady After London Bombings. Internet http:// pewforum.org/docs/index.php?DocID=89.

U.S. State Department. 2003. 2003 International Religious Freedom Report. Internet http://www.state.gov/g/drl/rls/irf/.

* $\quad$ Paper presented at the IASSIST 2006 conference in Ann Arbor in the session "Compare and Contrast: Using Cross-National Data”. Brian J. Grim, The Pew Forum on Religion and Public Life \& Association of Religion Data Archives. Roger Finke, Pennsylvania State University \& Association of Religion Data Archives. Direct correspondence to Brian J. Grim, bgrim@pewforum.org.

Supported by a grant from the John Templeton Foundation. The opinions expressed in this article are those of the authors and do not necessarily reflect the views of the Foundation. The data reported in this article were downloaded from the Association of Religion Data Archives, www.TheARDA.com, and were collected by Roger Finke and Brian J. Grim.

\section{Footnotes}

1 Major US university-based archives include the Interuniversity Consortium for Political and Social Research (ICPSR) at the University of Michigan, the Roper Center for Public Opinion Research at the University of Connecticut, the Howard W. Odum Institute for Research in Social Science at the University of North Carolina, The Henry A. Murray Research Archive and the HarvardMIT Data Center (HMDC), both members of the Institute for Quantitative Social Science at Harvard University. Other US university-based archives include the Cultural Policy and the Arts National Data Archive (CPANDA) at Princeton University, UC Data Archive and Technical Assistance (UC DATA) at UC-Berkeley, the Center for
International Earth Science Information Network (CIESIN) at Columbia University, the Social Sciences Data Archive (SSDA) at UCLA, the Data and Program Library Services (DPLS) at the University of Wisconsin-Madison, and the National Data Archive on Child Abuse and Neglect (NDACAN) Cornell University. Major European Archives include the Central Archive for Empirical Social Research at the University Cologne (which archives major surveys such as the ISSP and EVS). The Council of European Social Science Data Archives (CESSDA) provides a map of and links to the 21 major European archives, as well as links to five archives outside of North America and Europe (see map and links at http://www.nsd.uib.no/Cessda/europe. html).

2 The one country missing from this data set is the United States, due to the State Department's mission being limited to reporting on countries outside of the USA.

3 Afghanistan, Bangladesh, Bhutan, India, Nepal, Pakistan, and Sri Lanka

4 The Pearson correlations with religious tensions are: GRI .279 ( $\mathrm{p}=.001$, two-tailed $)$, GFI $.188(\mathrm{p}=.025$, two-tailed $)$, and SRI .463 ( $\mathrm{p}<.001$, two-tailed). All three of these indexes and the questions used to construct them, as well as the variable on religious tensions, are downloadable. They are also displayed online at an ARDA web page developed for each country. A more detailed description of the indexes and how they were created can be found in Grim \& Finke (2006). 